\title{
KONSTRUKTSIOONIPÕHINE KEELEMUDEL JA SÕNARAAMATUMUDEL
}

\section{Heete Sahkai}

\begin{abstract}
Ülevaade. Artiklis arutletakse võimaluse üle kajastada sõnaraamatus nähtusi, mis on olnud ajendiks konstruktsioonipõhise keelemudeli väljatöötamisele ning mis on problemaatilised nii leksikaalsel projektsioonil ja kompositsioonilisel semantikal põhinevate keeleteooriate kui traditsioonilise sõnaraamatumudeli jaoks. Artiklis vaadeldakse kolme tüüpi nähtusi: esiteks idiosünkraatilises morfosüntaktilises mallis kinnistunud sõnavormide erandlikku grammatilist käitumist, teiseks sõna esinemist mingis tähenduses ainult kindlates konstruktsioonides ja kolmandaks sõnavormide produktiivset esinemist eripärase vormi ja tähendusega konstruktsioonis. Kahe esimese nähtuse käsitlemiseks sõnaraamatus pakutakse välja konstruktsiooniploki lisamine sõnaartikli struktuuri, kolmanda nähtuse kirjeldamiseks tuleb aga leksikoni täiendada "konstruktikoniga".*
\end{abstract}

Võtmesõnad: leksikograafia, konstruktsioonigrammatika, süntaks, eesti keel

\section{Sissejuhatus}

Sõnaraamatu ülesehituse aluseks on meie ettekujutus keele ülesehitusest. Artiklis arutlen selle üle, millised järeldused võiksid tuleneda leksikograafia jaoks konstruktsioonipõhisest keelemudelist ja selle väljatöötamise ajendiks olnud nähtustest, mis on problemaatilised nii paljude alternatiivsete keeleteooriate jaoks kui ka traditsioonilise sõnaraamatumudeli seisukohast.

Nimelt on konstruktsioonipõhine lähenemine kasvanud välja tähelepanekust, et idiomaatiliste ja erandlike nähtuste osakaal keeles on senistes teooriates eeldatust oluliselt suurem ning neid ei saa esitada üksnes idioomide ja erandite lõpliku loeteluna, vaid nad võivad olla ka osaliselt produktiivsed ja reeglipärased (Fillmore jt 1988). Ehk teiste sõnadega, erandliku vormiga keeleväljendid, mille struktuur

Artikkel põhineb VI rakenduslingvistika konverentsil peetud ettekandel "Keelemudel ja sõnaraamatumudel" 
ei taandu neid moodustavate leksikaalsete üksuste kombinatoorsetele omadustele ja üldistele grammatilistele seaduspäradele, võivad olla moodustatud osaliselt produktiivse malli järgi, mis tähendab, et grammatilised seaduspärad võivad olla väga erineva üldisus- ja produktiivsusastmega. Ning teiselt poolt, idiomaatilist või mittekompositsioonilist tähendust ei pruugi kanda mitte ainult konkreetsed, kinnistunud sõnaühendid, vaid ka produktiivselt moodustatud väljendid, ehk tähendus võib olla seotud ka (osaliselt) produktiivsete morfosüntaktiliste mallidega.

Selliste osaliselt produktiivsete ja tähendust kandvate idiosünkraatiliste mallide representeerimiseks välja töötatud teooriates (nt Goldberg 1995, Kay, Fillmore 1999, Croft 2001) ei jagata keelelist teadmist leksikoniks ja grammatikaks, vaid leksikaalseid ja grammatilisi üksusi käsitletakse ühe kontiinuumina, mis ulatub sõnadest ja idioomidest osaliselt või täielikult skemaatiliste ja produktiivsete morfosüntaktiliste mallideni, millel võib samuti olla oma tähendus ja pragmaatiline funktsioon. See tähendab, et kõiki keelelise teadmise üksusi kujutatakse ühes formaadis, nn konstruktsioonidena, millel on kindel vorm, kombinatoorsed omadused ja (potentsiaalselt) tähendus ning pragmaatilised omadused. Seega kui enamikus teooriates kujuneb lause tähendus kompositsiooniliselt seda moodustavate leksikaalsete üksuste tähendustest, siis konstruktsioonipõhises mudelis võivad lause tähendusse oma panuse anda ka morfosüntaktilised mallid, nii et sõna tähendust kontekstis ei määra üksnes tema leksikaalne tähendus, vaid ka konstruktsioon, mille koosseisus ta esineb. Samuti ei ole lause vorm üksnes seda moodustavate sõnade kombinatoorsete omaduste peegeldus, vaid võib olla määratud ka seda moodustavate konstruktsioonide poolt, millel on samuti oma kombinatoorsed omadused: mitte üksnes sõnad ei "vali" oma süntaktilist ümbrust, vaid ka morfosüntaktilised mallid valivad sõnu, mis võivad nendes esineda. Ning et sellised mallid on väga erineva üldisusastmega, ei lange nende poolt valitud sõnade klassid alati kokku traditsiooniliste sõnaliikidega. Kui sõna on sellises idiosünkraatilises konstruktsioonis kinnistunud, võib selles esinemist pidada küll tema leksikaalseks omaduseks, ent tema süntaktilist käitumist ei saa sel juhul kirjeldada sõnaliigi terminites ning tema tähendust selles konstruktsioonis ei saa kirjeldada tema kontekstivälise tähendusena. Kui aga sõna esineb konstruktsioonis produktiivselt, ei saa tema süntaktilist käitumist ei taandada tema enda kombinatoorsetele omadustele ega kirjeldada sõnaliigi terminites.

Konstruktsioonipõhine lähenemine seab seega kahtluse alla kaks traditsioonilise sõnaraamatumudeli (ja paljude keeleteooriate) eeldustest: et sõnad jagunevad oma distributsiooni alusel suhteliselt väikeseks hulgaks sõnaliikideks, mis alluvad ühesugustele grammatilistele seaduspäradele, ning et sõnad on autonoomsed üksused, mille tähenduse lauses määrab nende inherentne leksikaalne tähendus ning mille morfosüntaktilise käitumise määravad nende endi kombinatoorsed omadused nagu sõnaliik ja rektsioonimall. Sellest tuleneb, et praegune sõnaraamatumudel jääb hätta juhtumitega, kus sõnade käitumist ei saa kirjeldada sõnaliigimärgenditega ning kus sõna tähendus ja/või süntaks on konstruktsioonispetsiifiline ehk seotud konkreetse morfosüntaktilise kontekstiga.

Leksikograafidele ei ole selliste nähtuste olemasolu muidugi uudis, kuid sõnaraamatumudeli aluseks olevast keeleteooriast sõltub see, kuidas sellistesse nähtustesse suhtuda. Seni on eeldatud (ja ka valitsevad keeleteooriad ennustavad), et selliste nähtuste näol on tegemist pigem üksikute marginaalsete eranditega. Konstruktsioonipõhine keelemudel aga ennustab, et tegemist on piisavalt ulatuslike, 
süstemaatiliste ja kesksete nähtusega keeles, et nendega sõnaraamatu struktuuri kujundades arvestada ning neid sõnaraamatut koostades sõnade tähendusest ja käitumisest süstemaatiliselt otsida.

Varem on idiosünkraatiliste ja idiomaatiliste konstruktsioonide leksikograafilisest käsitlemisest rääkinud konverentsiettekandes Charles Fillmore (2006) seoses täistekstide märgendamise kui uue menetluse kasutuselevõtmisega FrameNeti ${ }^{1}$ projekti raames. C. Fillmore’i nägemuse järgi peaks selle menetluse tulemusena sündima elektrooniline ressurss, mis koosneb kolmest komponendist: inglise keele leksikonist, kus on muuhulgas kirjeldatud sõnade esinemist erandlikes konstruktsioonides, wiki-põhimõttel täiendatavast inglise keele "konstruktikonist", kus konstruktsioonide kirjeldused on seotud neis esineda võivate sõnade kirjetega leksikonis (välja arvatud muidugi juhul, kui konstruktsioon on täiesti skemaatiline ega ole seotud konkreetsete sõnadega), ja märgendatud tekstid, kus on annoteeritud ka konstruktsioonid.

Artiklis püüan näidata, et konstruktsioonide kirjeldamine on vajalik ka traditsioonilises sõnaraamatus, ning pakun selleks välja spetsiaalse konstruktsiooniploki lisamise sõnaraamatu struktuuri (peatükk 2.1.). Konstruktsioonide kirjeldamise vajalikkus oleneb muidugi sõnaraamatu tüübist ja funktsioonist - võib eeldada, et ennekõike on see vajalik keeleõppijatele mõeldud sõnastikes. See, milline täpselt peaks olema sellise konstruktsiooniploki ülesehitus ja koht sõnaartikli struktuuris, jääb siiski veel edasise uurimise objektiks.

Illustreerin konstruktsiooniploki võimalusi ja piire kolme näitega. Artikli 2. osas kirjeldan põgusalt idiosünkraatilistes süntaktilistes mallides kinnistunud parameetersõnu, mille erandlikku süntaktilist käitumist konstruktsiooniplokk võimaldaks kirjeldada. 3. osas vaatlen sõna minema tähendusplokki 'alustama, hakkama, algama' EKSS-is ning püüan näidata, et tegemist on konstruktsioonispetsiifilise tähendusega, mille esinemiskontekste võiks samuti kirjeldada konstruktsiooniplokkides. 4. osas toon näite juhtumist, kus sõnade idiosünkraatilist süntaksit ja tähendust ei ole võimalik ka konstruktsiooniplokis kirjeldada, sest nad omandavad selle produktiivses konstruktsioonis esinedes. Selliste nähtuste kirjeldamiseks tuleks leksikoni täiendada "konstruktikoniga". 5. osas teen artiklist kokkuvõtte.

\section{Idiosünkraatiline grammatika}

Idiosünkraatilises konstruktsioonis kinnistunud sõnu, mille süntaktilist käitumist ei saa kirjeldada sõnaliigimärgendiga, sobivad näitlikustama parameetersõnadena toimivad nimisõnavormid. Tegemist on küllalt suure rühma sõnadega, millest paljud on sagedased ning mis asuvad leksikaalsete ja grammatiliste sõnade vahepeal, sest nad ei täida nimisõnadele omast referentsiaalset funktsiooni, kuid ei moodusta ka päris suletud klassi. Seega on tegemist funktsionaalselt oluliste sõnadega, millest sagedasemate käitumist võib olla vajalik kirjeldada eriti keeleõppijatele suunatud sõnaraamatutes.

Näiteks võib tuua konstruktsiooni, mis koosneb partitiivis parameetersõnast ja selle täiendist (nt ilusat värvi). Täiendiks võib olla kas adjektiiv- või genitiivatribuut, ${ }^{2}$ kuid mitte mõlemad korraga, samuti mitte relatiivlause. Seega ei käitu partitiivsed parameetersõnad reeglipäraste nimisõnadena, kuid neid ei saa paigutada üheselt ka mingisse muusse sõnaliiki. Sõnaraamatutes on neid küll

http://framenet.icsi.berkeley.edu/ (17.12.2007)

2 Seetõttu võib rääkida ka kahest erinevast mallist, [adjektiivatribuut + partitiivne N] ja [genitiivatribuut + partitiivne N]. Sellise lähenemise kasuks räägib see, et mõned partitiivsed parameetersõnad ei kombineeru vabalt mõlema atribuudiga, vaid eelistavad neist ühte, nt nägu eelistab genitiivatribuuti: vrd Ta on venna nägu, aga * $T a$ on vistrikulist nägu; mõned adjektiivid on siiski võimalikud, nt imelikku nägu. 
seostatud kaassõnadega, sest nimisõna- ja kaassõnafraasid täidavad lauses osaliselt samu funktsioone ning parameetersõnad nõuavad lisaks erinevalt enamikust nimisõnadest laiendit, meenutades sellega kaassõnu, kuid nende laiendamisvõimalused ei lange sageli kokku kaassõnade omadega. Kirjeldatud konstruktsiooni(de)s võivad esineda näiteks järgmised sõnad: laadi, moodi, stiili, liiki, tüüpi, sorti, klassi, tõugu, rassi, värvi, tooni, karva, mõõtu, kasvu, kaalu, nägu... Samas järgmised sõnad, mis on mingis mõttes sarnase tähendusega, mallis esineda ei saa, ehk tegemist ei ole päris produktiivse konstruktsiooniga: kategooriat, rahvust, hõimu, kuju, vormi, maitset, lõhna, välimust, ilmet...

Selliseid parameetersõnade malle on eesti keeles terve rida, igaüks veidi erineva vormi, distributsiooni ja produktiivsusega; morfoloogiliselt on neis esindatud enamus semantilisi käändeid, aga ka partitiiv, nagu eelpool illustreeritud. Sageli esinevad sama sõna vormid mitmes sellises konstruktsioonis. Näiteks sõnast mood on kolm parameetersõna, mis kõik käituvad erinevalt (vt tabel 1): moodi kombineerub adjektiivatribuudiga (A) ja genitiivatribuudiga (G) ning võib lauses toimida täiendi (Atr), öeldistäite (Pred) ja määrusena (Adv); moel võib kombineeruda adjektiiv- ja genitiivatribuudiga ja ka mõlemaga korraga $(\mathrm{A}+\mathrm{G})$, samuti relatiivlausega (Rel; nt Ta käitus moel, mis jättis ebaviisaka mulje), kuid saab lauses olla ainult määrus; moega võimaldab samu täiendeid nagu moel, välja arvatud relatiivlause, ent võib lisaks määrusele olla ka täiend ja öeldistäide. Ehkki laias laastus võib rääkida näiteks partitiivsest mallist, adessiivsest mallist ja komitatiivsest mallist, ei ole kõik samas käändes parameetersõnad siiski sama distributsiooniga: näiteks vïisil tundub käituvat samamoodi nagu moel; kombel aga mitte (vt tabel 1). Seega võib parameetersõnade süntaksit sageli käsitleda üksikute sõnade idiosünkraatilise käitumisena, mõnel juhul aga võib rääkida ka osaliselt produktiivsetest konstruktsioonidest.

Tabel 1. Parameetersõnade süntaktiline variatiivsus

\begin{tabular}{|l|c|c|c|c|c|c|c|}
\hline & A & G & A+G & Rel & Atr & Pred & Adv \\
\hline moodi & + & + & - & - & + & + & + \\
\hline moega & + & + & + & - & + & + & + \\
\hline moel & + & + & + & + & - & - & + \\
\hline kombel & + & + & - & - & - & - & + \\
\hline
\end{tabular}

Sõnaraamatu koostaja ette seavad sellised sõnad kaks probleemi: esiteks ei ole sõnavormi käitumine ennustatav algvormi põhjal, ehkki tähenduslik seos on olemas, ning teiseks ei ole see kirjeldatav sõnaliigimärgendiga. Morfoloogiliselt reeglipärased käändevormid on seega süntaktiliselt paradigmast eraldunud, kuid on säilitanud semantilise seose lähtesõnaga ning pole üle läinud ühtegi teise selgelt defineeritavasse sõnaliiki.

\subsection{Konstruktsioonid sõnaraamatus}

Sõnaraamatutes on selliste sõnade puhul kasutatud üldjoontes kolme tüüpi lähenemist. Esimene lähenemine on parameetersõnade esitamine vastavate nimisõnade reeglipäraste vormidena, st sõnavormi eripärast süntaksit parameetersõnana ei ole kirjeldatud (nt laadi, liiki, tüüpi EKSS-is) ega mõnel juhul ka näidetega illust- 
reeritud (nt tooni koos genitiivatribuudiga EKSS-is). Selline lähenemine kajastab parameetersõna semantilist seost lähtesõnaga, kuid mitte selle iseseisvat staatust ja süntaksit.

Teise võimalusena on parameetersõnad esitatud omaette märksõnadena ja nende käitumist on kirjeldatud erinevate sõnaliigimärgendite kombinatsioonidega, näiteks VVS-is on omaette märksõnad moodi Adv A Ks, laadi A, sorti A, karva Adv $A$, kuid mitte näiteks tüüpi, liiki, tooni, värvi, mõõtu, kasvu, kaalu, nägu, tõugu. Selline lähenemine kajastab parameetersõna iseseisvumist paradigmast, kuid nagu öeldud, ei ole sõnaliigimärgendid nende käitumise kirjeldamiseks piisavad.

Kolmas kasutatud lahendus on parameetersõnade eripärase käitumise informaalne kirjeldamine lähtesõna artiklis eraldi tähendusploki alguses. Seega on sellist lahendust kasutatud eelkõige siis, kui erandliku käitumisega kaasneb tähenduserinevus, nt EKSS-is on osaliselt kirjeldatud sõnu moodi, moel ja moega (nd 1), kuid mitte sõnu laadi, liiki, tüüpi. Kirjeldused ei ole siiski täielikud: mainitud on käändevorme, adjektiivatribuuti ja postpositsioonilaadsust (ehk genitiivatribuuti), kuid mitte distributsiooni lauses ega ka nende kolme erinevusi, sest sõnaartikli liigendus põhineb tähendusel.

\section{(1) $\operatorname{mood}$}

4. (hrl. partitiivis, adessiivis v. komitatiivis koos adjektiivse täiendiga:) viis, komme. ..

5. [gen.] hrl. substantiivi järel postpositsiooni laadis (väljendab tegelikult mingit sarnasusvõrdlust: kellegi, millegi sarnane v. sarnaselt). ..

6. (hrl. partitiivis:) liik, laad. Sõpru on mitut moodi. * Sealt kostis juba selle uut moodi pilli, lõõtsmoonika hääli.. A. Kalmus.

Kuna kõigil neil lahendustel on nii tugevusi kui nõrkusi, tundub kõige eelistatavam nende kolme kombinatsioon, mis võimaldaks kajastada nii parameetersõna semantilist seost lähtesõnaga (ja tagada tema leitavuse lähtesõna artiklist) kui tema iseseisvat staatust, ja ühtlasi kirjeldada tema erandlikku grammatikat. Sellise lahenduse näiteks sobib sõna kombel esitus EKSS-is (nagu eelpool toodud näidetest näha, ei ole sellist esitusviisi kasutatud siiski süstemaatiliselt).

(2) kombel vt. komme.

komme, kombe $^{19} \mathrm{~s}$.

4. kombel (mingil) viisil, moel, moodi. a. koos eelneva (ühilduva) omadus- v. asesõnaga (mõnikord on asendatav vastavast omadus- v. asesõnast tuletatud adverbiga). .. || koos sõnadega kole, hirmus, armetu, hale jms. väljendab millegi rohkust v. intensiivsust. .. b. [gen.] hrl. nimisõna järel postpositsiooni laadis (väljendab tegelikult võrdlust eelneva nimisõnaga: mehe kombel 'nagu mees' jne.). .. c. kõnek. koos määrsõnaga. . .

Kombel on antud omaette märksõnana viitega artiklile komme, kus ta on rasvaselt esile tõstetud omaette tähendusplokis ja esitatud otse adessiivivormis, mitte lihtsalt sulgudes kirjeldusega "hrl. adessiivis", nii et see on kasutaja jaoks kergelt leitav; lisaks on allplokkides kirjeldatud informaalselt erinevaid konstruktsioone, milles kombel esineb. 
Seega on tuntud vajadust kirjeldada sõnavormide iseseisvat ja eripärast käitumist ka muude vahenditega peale sõnaliigimärgendite, kuid sellised kirjeldused ei ole täielikud ega süstemaatilised ning nende jaoks ei ole loodud sõnaraamatu struktuuris omaette kohta. EKSS-is on eripärase vormi ja käitumise kirjeldus seotud märksõna tähenduse seletusega, ent nagu toodud näidetestki ilmneb, ei saa märksõna vormide eripärast käitumist alati siduda märksõna iseseisva tähendusega: nt sõna kombel puhul on tähendus omistatud märksõna kindlale vormile, mitte märksõnale endale, ning teiselt poolt sõnade nagu liik, tüüp või laad vormide tähendus parameetersõna konstruktsioonis ei eristu piisavalt märksõnade leksikaalsest tähendusest, et anda alust omaette tähendusploki loomiseks. Samuti ei võimalda selline lahendus kirjeldada juhtumeid, kus sõna esineb samas tähenduses erinevates konstruktsioonides, nt artikli järgmises osas vaatlen verbi minema esinemist tähenduses 'alustama, hakkama, algama' ja püüan näidata, et see tähendus on konstruktsioonispetsiifiline, kuid esineb mitmes konstruktsioonis.

Kui tähenduse seletuse juures esitatud grammatikakirjeldus on allutatud tähendusel põhinevale liigendusele, ehk täpsustatud on märksõna ühe tähenduse kasutuskontekste, siis sõnaliigimärgenditel põhinev grammatikakirjeldus on tähenduse suhtes primaarne - nt sõna all tähendust postpositsioonina ja adverbina on seletatud ühtemoodi, kuid sõnaliigierinevuse tõttu on nad esitatud erinevates struktuuriüksustes. Kuid ka sõnaliigi väli on mõeldud märksõna, mitte selle vormide kirjeldamiseks ega sobi seetõttu selliste konstruktsioonide kirjeldamiseks, milles märksõna võib esineda ainult kindlas vormis. Teiste sõnadega, oleks eksitav esitada samas numeratsioonis vaheldumisi informatsiooni märksõnaks oleva lekseemi ja selle üksikute vormide kohta.

Veel üks võimalus konstruktsioonide kirjeldamiseks oleks fraseologismiplokk on ju idiosünkraatilise vormi ja/või mittekompositsioonilise tähendusega konstruktsioone nimetatudki "formaalseteks idioomideks" (Fillmore jt 1988: 505-506). Ka selliste konstruktsioonide näol on tegemist sõnast suuremate üksustega, kus sõna esineb kindlas vormis ja/või tähenduses ning millel endal on oma kindel vorm ja tähendus. Kuid nagu C. Fillmore jt sealsamas märgivad, võivad idioomid põhineda konstruktsioonidel, ehk vajalikuks võib osutuda konstruktsiooni illustreerimine idioomiga. ${ }^{3}$ Seega võiks konstruktsioonide kirjeldamiseks ette näha omaette ploki, mille ülesehitus oleks sarnane fraseologismiplokiga (näiteks EKSS-is on fraseologismiplokis koht seletuse, märgendite ja näidete jaoks, vt 1. kd lk 8 p 26), kuid mis võiks allüksusena sisaldada ka fraseologismiplokki. Samuti on võimalik, et juhtudel, kus sõna või sõnavorm esineb samas tähenduses mitmes konstruktsioonis (nagu minema järgmises peatükis illustreeritud konstruktsioonides), on vajalik eraldi kirjeldada sõna(vormi) tähendust konstruktsioonis ja konstruktsiooni kui terviku tähendust; ei ole ka välistatud, et ühel konstruktsioonil võib olla mitu tähendust, märgendit vms. Seega kui fraseologismid on EKSS-is esitatud alati sõnaartikli lõpus, siis konstruktsioone kui vähem idiomaatilisi üksusi võib olla otstarbekas kirjeldada ka tähendusplokkide sees.

Konstruktsiooniploki kasutuselevõtt tähendaks, et sõnaartiklisse toodaks märksõna sõnaliikide, tähenduste ja märksõna sisaldavate fraseologismide kõrval sisse veel üks sõltumatu liigendusalus: märksõna (vorme) sisaldavad erandliku ehituse ja/või mittekompositsioonilise tähendusega konstruktsioonid. See võimaldaks näiteks luua omaette ploki parameetersõnade liiki või tü̈̈pi süntaktilise käitumise kirjeldamiseks

${ }^{3}$ Idioomide ja idiomaatiliste konstruktsioonide tihe seos tuleb välja ka järgmises peatükis, kus käsitletakse minema esinemist algamist või alustamist väljendavas tähenduses nii püsiühendites kui osaliselt produktiivsetes mallides. 
hoolimata sellest, et nad ei anna alust omaette tähendusploki loomiseks. Sõnaliigimärgendi tähendus konstruktsiooniploki lisamisest ei muutuks: kuna ka praegu on sõnaartiklis olemas täiendavad grammatilise käitumise kirjeldamise vahendid, mõistetakse sõnaliigimärgendit järelikult juba praegu vaikimisi kehtiva üldistusena, millest tulenevad implikatsioonid saab tühistada täpsustavate kirjeldustega. Samuti säiliks võimalus anda grammatilist infot märksõna üksikute tähenduste kohta.

Kuidas täpselt oleks otstarbekas konstruktsioone sõnaraamatus kirjeldada, on siiski keeruline küsimus ja jääb käesolevas artiklis lahtiseks. Artikli eesmärk on eelkõige põhjendada konstruktsioonide kirjeldamise vajalikkust omaette struktuuriüksuses.

Võib tekkida küsimus konstruktsioonide kirjeldamise teostatavusest: peaks ju sõnaraamatu koostaja sellisel juhul lisaks tähendusele analüüsima küllalt detailselt ka sõna süntaktilist käitumist. Sellise analüüsi teostatavuse kasuks räägib siiski see, et nagu eeltoodud näidetest näha, on seda ka seni osaliselt tehtud. Ka on see vajalik ainult kindlat tüüpi sõnaraamatutes, eelkõige õppesõnastikes, ning eelkõige sagedasemate sõnade puhul. Lisaks peaks konstruktsioonide kirjeldus jääma kasutajasõbralikkuse huvides informaalseks nagu senigi ega peaks olema põhjalikum kui tavapärane semantiline ja grammatiline analüüs.

Samuti võib küsida, kas selliste idiosünkraatiliste nähtuste osakaal keeles on piisavalt suur, et nendega sõnaraamatu struktuuris arvestada. Konstruktsioonipõhine keelemudel ennustab, et see on vajalik, kuid seni on siiski tegemist hüpoteesiga, mida tuleb alles kontrollida. See, milline keelemudel on sõnaraamatumudeli aluseks, ongi tähtis seetõttu, et andmestikus märgatakse eelkõige seda, mida oodatakse seal olevat. Kui lähtutakse eeldusest, et sõnad käituvad valdavalt reeglipäraselt ning nende tähendus kontekstis tuleneb nende leksikaalsest tähendusest, siis ei märgata nende võimalikke erandlikke omadusi ega konstruktsioonispetsiifilisi tähendusi. Alles teadlik lähtumine konstruktsioonipõhisest keelemudelist või hüpoteesist, et sellise mudeli ajendiks olevad nähtused on keeles seni eeldatust sagedasemad, teeb võimalikuks nende nähtuste märkamise ja nende ulatuse kindlakstegemise.

Mingi ettekujutuse idiosünkraatiliste nähtuste osakaalust annab see, et juba näiteks toodud parameetersõnad moodustavad üsna suure rühma ning on lisaks suhteliselt sagedased ja ka teataval määral funktsioonisõnad. Kindlasti pole parameetersõnad ainuke selline rühm. Üheks näiteks sellisest sõnaklassist eesti keeles, mida ei saa kirjeldada traditsiooniliste sõnaliigimärgenditega, võib tuua seisundisõnad, millel on nii adverbide kui adjektiivide jooni (vt Tiits 1982). C. Fillmore nimetab eelpool viidatud ettekandes selliste sõnade hulgas ka ajaväljendeid ja arvsõnu. Ühe universaalse grammatiseerumisnähtusena, millega kaasnevad samalaadsed kirjeldusprobleemid, võib nimetada nimisõnade grammatiseerumist nimisõnalises kvantorifraasis (vt Koptjevskaja-Tamm (2001), Traugott (käsikiri)). Näiteks eesti keeles on hulganimisõnadel mitmeid arvsõnade omadusi (EKG II: 144-145, Koptjevskaja-Tamm 2001: 536-540) ning nad võivad olla sihitisena muutumatud (Erelt 2000: 94-95).

Kokkuvõtteks, paradigmast iseseisvunud sõnavormide eripärase süntaksi kirjeldamiseks võiks lisada sõnaraamatu struktuuri fraseologismiplokiga sarnase konstruktsiooniploki ning lisaks esitada sõnavormi märksõnaviitena. Järgmises osas vaatlen konstruktsiooniploki kasutamist konstruktsioonispetsiifilise tähenduse konteksti(de) kirjeldamiseks. 


\section{Konstruktsioonispetsiifiline tähendus}

Artikli selles osas illustreerin juhtumit, kus sõna kannab teatud tähendust ainult kindlate konstruktsioonide koosseisus, st tegemist on konstruktsioonispetsiifilise tähendusega. Niisuguse tähenduse esitamine sõnaraamatus sõna leksikaalse, kontekstivälise tähendusena võib olla eksitav taas eelkõige keeleõppijatele mõeldud sõnastikus. Seetõttu võib osutuda vajalikuks sellise tähenduse esinemiskontekstide kirjeldamine, milleks sobib samuti konstruktsiooniplokk.

Näiteks konstruktsioonispetsiifilisest tähendusest võib tuua sõnaartikli minema 6. tähendusploki 'alustama, hakkama, algama' EKSS-is.

(3) minema

6. protsessi v. tegevust alustama; hakkama, algama, puhkema. Mootor ei tahtnud käima minna. Uus elektrijaam läheb käiku. Lind läks lendu. Maja läks välgust põlema. Ahi läks hõlpsasti küdema, kütte. Kohvivesi läks keema. Haav läks mädanema. Mahl on käärima, pealt hallitama läinud. Selline kuuldus, kumu on liikuma, liikvele läinud. Istutasin kadaka, aga see läinud kasvama. Koerad läksid purelema. Eks katsu minna rahva vastu! Läheb nü̈d sulane peremehega maid jagama! Läksid omavahel vaidlema, nägelema, tülli, rïdu, raksu, käsitsi kokku, kaklema, kiskuma. Läks vaidluseks, ütlemiseks, nägelemiseks, tüliks. Nüüd läheb löömaks, mölluks, madinaks, raginaks. Hommikul läheb sõiduks. Traktoristidel kippus palgapäeviti viinavõtmiseks minema. *Kas siis mõni kaupmees teil kahjuga kauplema läheb, hurjuh! O. Luts. | läks! las läheb, las minna. Tähele panna! Valmis olla! Läks! *.. (valab Filosoofile veiniklaasi konjakit täis): Läks! E. Rannet.

See plokk jaguneb tegelikult erinevateks konstruktsioonideks, millest osa on kinnistunud ühendid, osa teatud määral produktiivsed, kuid mitte kirjeldatavad verbi minema rektsioonina. Väljaspool neid kontekste ehk vabalt kombineerudes minema sellist tähendust ei kanna.

Esimene tüüp vaatlusaluses tähendusplokis illustreeritud konstruktsioone on püsiühendi laadsed juhtumid: käiku / lendu / kütte / liikvele / kasvama / tülli / rïdu / raksu / käsitsi kokku minema. Üleminek sarnase tähendusega püsiühendite rühma ja mingi tähendusrühma piires produktiivse malli vahel on muidugi sujuv, kuid pigem püsiühenditest võib rääkida siis, kui ühendis esinev laiendsõna ei ole ka lähedaste sünonüümidega vabalt asendatav. Näiteks ritta tülli / rïdu / raksu minema võib lisada ka ühendid naginasse / raginasse minema, kuid mitte enam väljendeid \#sõnavahetusse / sõimlusse / rïdlemisse / nägelusse minema.

Teiseks on tähendusplokis illustreeritud mõned produktiivsed konstruktsioonid. Esimene neist koosneb verbist minema ja füüsilist või verbaalset konflikti väljendava verbi ma-infinitiivist: vaidlema / nägelema / kaklema / kiskuma minema. Ka siin ei ole tegemist vaba ühendiga, sest Poisid läksid õues kaklema tähendab küll 'poisid hakkasid kaklema', kuid Poisid läksid sööma/mängima ei tähenda sama mis 'poisid hakkasid sööma/mängima'. Samas on mall produktiivne, st tegemist ei ole üksikute väljendverbidega, vaid selles võivad esineda kõik antud tähendusrühma kuuluvad verbid, mille hulk on avatud, sest sellesse tähendusrühma lisandub 
pidevalt ekspressiivseid, kujundlikke või slängisõnu. Konstruktsiooni produktiivset kasutust illustreerivad järgmised Google’i otsingumootoriga leitud näited.

(4) Poisid läksid Gerly pärast kätsima :) ! (myass.ee/My\%2oWeb\%20Sites/ joulupyhad.htm 17.12.2007)

.. mängijad ja treenerid läksid alaliiduga lubatud tasude pärast kraaklema. (etvsport.ee/index.php?0539507 17.12.2007)

Keskerakond ja sotsid läksid valimiskomisjoni ukse taga kähmlema. (www. postimees.ee/150404/online_uudised/131607.php 17.12.2007)

Järgmine konstruktsioon koosneb minema ainsuse 3. isiku vormist ja tegevusnimisõna translatiivist: vaidluseks / ütlemiseks / nägelemiseks / tüliks / löömaks / mölluks / madinaks / raginaks / sõiduks / viinavõtmiseks minema. Eriti mineteonimega, kuid ka teiste tegevusnimisõnadega on see mall üsna produktiivne, nagu näitavad Internetist leitud laused näites 5 , kuid ka seda malli ei saa kirjeldada minema rektsioonimallina, sest minema peab selles esinema kindlas vormis.

(5) Peale sööki läks köögi ja koridori tapeetimiseks. (www.misjon.ee/index. php?id=17 17.12.2007)

Pidutsemiseks läheb kella kümnest. (www.ehh.ee/index.php?main_ id=8\&news_id $=154$ 17.12.2007)

Läks jubedaks kisaks ja sagimiseks. (velo.clubbers.ee/foorum/viewtopic. php?start=175\&t=9923 17.12.2007)

Igatahes mai algul läheb tööks ja mõne nädalaga peaks kõik korda saama. (vana.www.sakala.ajaleht.ee/rubriigid.html?number=603 17.12.2007)

Varsti läheb reisiks läbi Praha Dubaisse. (trip.ee/node/17052 17.12.2007)

Veel üks vaadeldavas tähendusplokis illustreeritud mall koosneb verbistminema ja ma-infinitiivis seisundi-, protsessi- või liikumisverbist: käima / liikuma / põlema / küdema / keema / mädanema / käärima / hallitama minema. Selles mallis esineda võivate verbide hulk on küll suur, kuid piiratud kindlate tähendusrühmadega. Näiteks tundub, et minema ei esine tähenduses 'hakkama' ühenduses psühholoogilist seisundit väljendavate verbidega, vrd \#Läksin kurvastama / rõõmustama, aga ka mitmete muude protsessi- ja seisundiverbide tähendusrühmadega, vrd Maja läks põlema, aga \#Maja läks lagunema, vajuma; Vesi läks keema, aga \#Vesi läks jahtuma, lainetama, purskama, tõusma; Haav läks mädanema, aga \#Haav läks valutama, veritsema, sügelema, paranema, armistuma.

Kirjeldatud tähendusplokis on veel kinnistunud vormel Läks! ja üks pragmaatilise funktsiooniga lausemall, mida illustreerivad näitelaused Läheb nüüd sulane peremehega maid jagama! ja Kas sïs mõni kaupmees teil kahjuga kauplema läheb, hurjuh! Kui muuta need laused neutraalseteks väitlauseteks (Sulane läks peremehega maidjagama, Kaupmees läks kahjuga kauplema), ei tähenda minema enam 'hakkama', ehk see tähendus on antud juhul seotud konkreetse lausemalliga.

Viimaks on plokis veel näitelause Eks katsu minna rahva vastu!, kus minema ei tundu tähendavat 'alustama' või 'hakkama' ning mis on tähendusplokki sattunud võib-olla sellepärast, et vastu minema on siin sünonüümne ühendverbiga vastu hakkama. ${ }^{4}$

4 Üks osaliselt produktiivne konstruktsioon, mis kirjeldatud tähendusplokist puudub, on minema 3. isiku vorm 
Seega võib öelda, et kõik näited, mis illustreerivad verbi minema kasutamist tähenduses 'alustama, algama, hakkama', illustreerivad kas konkreetseid püsiühendeid või osaliselt produktiivseid idiomaatilisi malle, mida ei saa esitada minema rektsioonina, nt kujul [minema $+m a$-infinitiiv], sest nad on piiratud kindlate tähendusrühmadega või verbi kindla vormiga. Seega on verbil minema tähendus 'alustama, algama, hakkama' ainult kindlates konstruktsioonides. Selle tähenduse esitamine minema leksikaalse tähendusena võib olla eksitav eelkõige eesti keele õppijatele suunatud sõnastikes, sest tegemist on tavalise tähendusülekandega ja paljudes keeltes on verb minema inhoatiivse või tuleviku abiverbina täielikult grammatiseerunud. Ka siin võiksid lahenduseks olla konstruktsiooniplokid, kus kirjeldatakse põgusalt neid kontekste, milles verb vastavat tähendust kannab. Omaette lahendust nõuavad aga püsiühendid, mis on rohkem käsitletud teema (Muischnek 2006, Veldi 2006).

Küsimus, kas eeltoodud näide illustreerib üksikjuhtu või üldisemat nähtust, nõuab muidugi uurimist, kuid asjaolu, et minemisverbi grammatiseerumine aspektuaalseks või temporaalseks abiverbiks on universaalne nähtus (vt nt Heine, Kuteva 2002: 161-163), viitab pigem sellele, et tegu ei ole ainulaadse näitega. Võib oletada, et nii nagu 2. osas toodud näide kehtib parameetersõnade kohta laiemalt, nii võib ka see näide kehtida üldisemalt verbide kohta, mis võivad abiverbistuda, sest grammatiseerumine algab alati kindlas kontekstis (Heine, Kuteva 2002: 2). Selliste verbide kandidaatideks on tuumverbid (olema, tegema, tulema, minema, käima, seisma, istuma, saama, võtma, andma, panema, vïma, tooma, pidama, võima, hakkama, ajama, laskma, jääma ning kognitiiv-ja suhtlusverbid - vt Pajusalu jt 2004: 11-12). Tundub, et konstruktsioonispetsiifilisi tähendusi kalduvad omandama ka verbid, mis moodustavad sageli püsiühendeid (tegema, minema, andma, saama, panema, võtma, ajama,jääma, pidama, lööma - vt Muischnek 2004: 576), millest omakorda võivad välja kasvada poolproduktiivsed mallid (näiteks reeglipärast mine-teonime sisaldavatele poolproduktiivsetele mallidele võivad vastata sarnase tähendusega verbi-nimisõna püsiühendid ning ka verbiühenditel võib olla paralleelseid verbinimisõna püsiühendeid, vrd nt kaklema minema ja tülli minema).

Kokkuvõtteks, väljapakutud konstruktsiooniplokki saaks kasutada ka juhul, kui sõnal on konstruktsioonispetsiifilisi tähendusi, mille konteksti kirjeldamine on vajalik. Järgmises peatükis vaatlen aga juhtumit, mis illustreerib konstruktsioonide kirjeldamise piire.

\section{Produktiivne konstruktsioon}

Võimalusel kirjeldada konstruktsioone sõnaraamatus on ka oma piirid: sõna konstruktsioonispetsiifilist süntaksit ja tähendust saab sõnaraamatus kirjeldada üksnes siis, kui sõna on eripärase vormi ja/või tähendusega konstruktsioonis kinnistunud, nii nagu üksikud parameetersõnad oma mallides või verb minema artikli 3. osas kirjeldatud konstruktsioonides; ehk teistpidi öeldes, sõnaraamatus saab kirjeldada ainult konstruktsioone, mis sisaldavad kindlaid sõnu või sõnavorme. Kui aga sõna omandab konstruktsioonispetsiifilise tähenduse või süntaksi tänu kombineerumisele produktiivse konstruktsiooniga, milles esineda võivate sõnade hulk on avatud, ei saa sõna eripärast käitumist ja/või tähendust selles konstruktsioonis sõnaraamatus 
kuidagi kirjeldada. Teiste sõnadega, sõna esinemist selles konstruktsioonis ei saa esitada tema leksikaalse omadusena, sest selle tingivad konstruktsiooni, mitte sõna kombinatoorsed omadused. See, et tähendust ei saa kirjeldada ega grammatikat annoteerida ainult sõnade loendi kujul ehk sõnaraamatus, on ootuspärane, kui keeleline teadmine ei jagune leksikoniks ja (suurelt osalt sõnade kombinatoorsetele omadustele taanduvaks) grammatikaks, vaid moodustab ühe erineva üldisusastmega sümboolsete üksuste võrgustiku. Seega tuleb konstruktsioonipõhisest perspektiivist lähtudes täiendada sõnaraamatut ja seal sõnaliigimärgenditega indekseeritavat traditsioonilist grammatikat n-ö "konstruktikoniga" sissejuhatuses refereeritud C. Fillmore'i ettekande mõttes (Fillmore 2006). ${ }^{5}$

Näiteks poolproduktiivsest konstruktsioonist, mida ei saa sõnaliigimärgendiga indekseerida ega konstruktsiooniplokis kirjeldada, võib tuua adessiivse viisi- ja põhjusmääruse, mida illustreerivad järgmised näited (lähemalt vt Sahkai 2006).

(6) Eesti Kirjameeste Seltsi otsusel mindi 1872 üle uue kirjaviisi kasutamisele. (http://www.miksike.ee/docs/referaadid/rahvuslik_liikumine.htm 17.12.2007)

See on lugu kõrgel kohal asjamehest, kes FBI sundimisel pidi üle kahe aasta suurfirma hämaraid asju nuhkima. (http://movies.ee/uudis/996/ 17.12.2007)

Konstruktsioon toimib lauses määrusena ja koosneb adessiivis tegevusnimisõnast ja selle tegevussubjekti vormistavast genitiivsest nimisõnafraasist. Sellist määrust sisaldavad laused koosnevad seega kahest propositsioonist, kusjuures põhipropositsioon (esimeses näitelauses 1872 mindi üle uue kirjaviisi kasutamisele) on tõlgendatav sekundaarse predikaadina toimiva tegevusnimisõna semantilise argumendina. Konstruktsiooni põhjana esinevad sõnad omandavad selles tunnuseid, mida ei saa pidada nende leksikaalseteks omadusteks: teonime semantilisi argumente ei realiseerita laienditena nimisõnafraasis (vrd ?Eesti Kirjameeste Seltsi otsusel hakata looma ühist kirjakeelt mindi 1872 üle uue kirjaviisi kasutamisele.), mitteprotsessuaalsed teonimed omandavad protsessuaalse tähenduse ja tavaliselt objektatribuudiga kombineeruvad teonimed saavad kombineeruda ainult subjektatribuudiga: nt soosing on tavaliselt mitteprotsessuaalse tähendusega ja kombineerub subjektatribuudiga ning soosimine protsessuaalse tähendusega ja kombineerub objektatribuudiga, ${ }^{6}$ antud konstruktsioonis aga on mõlemad protsessuaalse tähendusega ja kombineeruvad subjektatribuudiga:

(7) .. linnavõimude soosingul on avalikud huvid tagaplaanile surutud .. (www.parnupostimees.ee/101106/kommentaarikeskus.php?ARTIKKEL_ ID=10069109\&TASK=KOMMENTAARID 17.12.2007)

.. tema soosimisel vohab firmas le travail clandestin ehk ebaseaduslik töö. (http://arhiiv2.postimees.ee:8080/leht/99/02/06/valised.htm 17.12.2007)

Et konstruktsioonis esineda võivate nimisõnade hulk ei ole piiratud konkreetsete sõnadega, vaid üksnes kindlate tähendusrühmadega, ei saa neid konstruktsioonispetsiifilisi omadusi esitada sõnaraamatus üksikute sõnade omadustena. Näiteks võib Internetiotsinguga leida sellest konstruktsioonist järgmisi sõnavorme, mis

5 Ülle Viks juhtis mu tähelepanu sellele, et eesti keele kohta on üks konstruktikoni-laadne ressurss juba olemas:

6 Protsessuaalsete ja mitteprotsessuaalsete teonimede genitiivatribuudi subjektilisusest ja objektilisusest vt Kasik 1968: 133. 
sageduse järgi otsustades ei ole selles konstruktsioonis kinnistunud ja esindavad seega konstruktsiooni produktiivset kasutust: (midagi tehti kellegi) finantstoetusel /inspiratsioonil / kaasalaulmisel / kaasamängimisel / kureerimisel/moosimisel / nïditõmbamisel / promomisel / sobitusel / tagantsundimisel / taganttorkimisel...

Paljud sõnavormid on selles konstruktsioonis siiski kinnistunud ning selliste vormide erandlikku süntaksit ja/või tähendust saab sõnaraamatus kirjeldada konstruktsiooniplokis; näiteks kinnistunud vormidest võib tuua sõnad abil, ettepanekul, käsul, loal, nõusolekul, osavõtul, saatel, soovitusel, toel...

Selliste kinnistunud juhtude praegune esitus sõnaraamatus kajastab traditsioonilist eeldust, mille järgi sõna tähendus kontekstis tuleneb tema leksikaalsest tähendusest ning sõna süntaktilise käitumise määravad tema leksikaalsed kombinatoorsed omadused: konstruktsioonispetsiifilist protsessuaalset tähendust on kirjeldatud sõna leksikaalse tähendusena ning erandlikku süntaksit on käsitletud sõnavormi leksikaalse kategooriamuutuse (kaassõnastumise) tulemusena. Sellist lähenemist võib illustreerida vaatlusaluses konstruktsioonis kinnistunud vormide toimetusel ja kirjastusel esitusega EKSS-is. Sõna kirjastus artikli teine tähendusplokk illustreerib konkreetse sõnavormi konstruktsioonispetsiifilise tähenduse omistamist märksõnale, mis võib taas olla eksitav keeleõppija jaoks.7

(8) kirjastus, -e $5 \mathrm{~s}$.

1. mitmesuguseid trükiseid kirjastav ettevõte. ..

2. kirjastamine. Romaan ilmus "Postimehe", autori enda kirjastusel.

Artikkel toimetus illustreerib sõna eripärase käitumise kirjeldamist kategooriamuutusena.

(9) toimetus, -e $5 \mathrm{~s}$.

1. toimetamine, talitus, tegemine, toiming, töö. ..

2. toimetusel (postpositsioonile lähedasena:) kellegi poolt toimetatuna (4. täh.). J. V. Jannseni toimetusel ilmunud ajaleht. Kooli almanahh anti välja ôpilaste endi toimetusel.

3. ajalehte v. ajakirja väljaandev asutus v. organ, samuti selle v. kirjastuse, raadio mingi osakond; selle tööruum(id)...

Kaassõnadeks ei saa selles konstruktsioonis kinnistunud sõnu siiski pidada nende tähenduse tõttu, avatud sõnarühma kuulumise tõttu ega võimaluse tõttu kombineeruda adjektiivatribuudiga, nt (10).

(10) Samalt autorilt ja A. L.-i tehnilisel toimetusel ilmus 2000. aastal "Inimese füsioloogia”. (http://biomedicum.ut.ee/arfs/ajalugu/tartu_ulikooli_fusioloogia_instituut_1981-2006/oppetoo/ 17.12.2007)

Toodud näited illustreerivad veel kord selliste juhtumite senise käsitlemise variatiivsust; seda näitlikustab ka see, et sünonüümsed vormid toimetamisel ja kirjastamisel ei kajastu sõnaraamatus üldse, sest reeglipäraseid mine-teonimesid üldise reeglina omaette märksõnadena ei esitata.

Ka see on empiirilise uurimise küsimus, kui palju on keeles selliseid produktiivseid konstruktsioone, mida ei saa kirjeldada sõnaliikide terminites. Näiteks toodud konstruktsiooni võib pidada suhteliselt marginaalseks, samas näitab Maria-Maren Sepper (2006: 54-56), et see konstruktsioon on muutunud viimastel aastakümne- 
tel üheks peamiseks vahendatud väite vormistamise viisiks ajakirjanduskeeles (nt lauses Tõnissoni ütlusel tuleb vend tagasi, Sepper 2006: 49). Peamiselt kasutatakse selleks konstruktsioonis kinnistunud vorme, mida saab sõnaraamatus kirjeldada (nt sõnul, teatel, väitel), kuid on ka vorme, mida on selles mallis kasutatud ilmselt produktiivselt (nt olen Internetiotsinguga leidnud sellest konstruktsioonist järgmisi vorme: ennustusel, hoiatusel, järeldusel, kartusel, lubadusel, meenutusel, mäletamisel, rõhutusel, seletusel, selgitusel, veendumusel, viiteil, viitel). Need sõnad moodustavad aga ainult ühe konstruktsioonis esineda võivatest tähendusrühmadest (vt Sahkai 2006).

Eelkirjeldatud konstruktsiooniga sarnased on häält väljendavate - $n$-deverbaalide adessiivivormid (nt mürinal), millest paljud on esitatud nt VVS-is adverbidena (VVS: 786-787). Tegemist on siiski produktiivse konstruktsiooniga, milles esinevad vormid ei käitu reeglipäraste nimisõnadena, kuid neid ei saa kirjeldada ka adverbidena, sest nad võivad kombineeruda genitiiv- ja adjektiivatribuudiga, nt (11).

(11) Kui igipedajad metsadest traktorite mürinal lahkuvad .. (www.loodusajakiri. ee/eesti_loodus/EL/vanaweb/9805/kotkad.html 17.12.2007)

Pole aimugi, mis toimub Eestis ja kogu maailmas just nüüdsama, sel hetkel, kui masin monotoonsel mürinal seda Päevalehe soovitud arvamuslugu trükib. (www.epl.ee/artikkel_275118.html 17.12.2007)

Samalaadseks nii sõnaliikide kui vormi- ja sõnamoodustuse piire ähmastavaks nähtuseks eesti keeles võib pidada nimisõnade nn seisundivorme, millest paljud on samuti kinnistunud, kuid mida saab moodustada ka produktiivselt; teiste sõnadega, nimisõnast saab moodustada produktiivselt seisundisõnu, mis langevad vormiliselt osalt kokku ühe käändevormiga, kuid mis ei käitu nagu nimisõnad ja mida ei saa üheselt kirjeldada ka kui adverbe või adjektiive (vt Tiits 1982). Näiteks võib produktiivselt moodustatud seisundivormideks pidada sõnu rihmas ja suukorvis järgmises lauses (vrd ?Koer olgu lühikeses rihmas).

(12) .. looduses olgu koer rihmas ja suukorvis. (www.rmk.ee/pages.php3/010303 17.12.2007)

Kokkuvõtteks, produktiivses konstruktsioonis kinnistunud sõnade või sõnavormide käitumist ja tähendust on võimalik taas kirjeldada konstruktsiooniplokis, sellises konstruktsioonis produktiivselt esinevate sõnade idiosünkraatilist käitumist ja/või tähendust saab aga kirjeldada ainult "konstruktikonis".

\section{Kokkuvõte}

Vaatlesin artiklis kolme tüüpi nähtusi, mis on problemaatilised nii leksikaalsel projektsioonil ja kompositsioonilisel semantikal põhinevate keeleteooriate jaoks kui traditsioonilise sõnaraamatumudeli jaoks. Nendeks olid esiteks idiosünkraatilises morfosüntaktilises mallis kinnistunud sõnavormide erandlik grammatiline käitumine, teiseks sõna esinemine mingis tähenduses ainult kindlates konstruktsioonides ja kolmandaks sõnavormide produktiivne esinemine eripärase vormi ja tähendusega konstruktsioonis. Selliste nähtuste kajastamine sõnaraamatus on problemaatiline, sest idiosünkraatilist grammatilist käitumist ei saa kirjeldada või 
indekseerida traditsioonilise sõnaliigimärgendiga ning konstruktsioonispetsiifilist tähendust ja grammatikat ei saa esitada märksõna leksikaalsete omadustena. Konstruktsioonipõhine keelemudel aga ennustab, et selliseid nähtusi on keeles rohkem kui seni eeldatud, mistõttu nende kirjeldamine on vajalik eriti keeleõppijatele suunatud sõnastikes. Pakkusin välja, et kahte esimest nähtust, sõnavormide eripärast käitumist ja konstruktsioonispetsiifilise tähenduse esinemiskontekste, võimaldaks sõnaraamatus kirjeldada fraseologismiploki taolise konstruktsiooniploki lisamine sõnaartikli struktuuri. Lähtumine eeldusest, et idiosünkraatilisust ja idiomaatilisust on sõna(vormi)de käitumises ja tähenduses seniarvatust rohkem, tähendab muidugi ka seda, et sõnaraamatu koostaja peab seda andmestikust süstemaatiliselt otsima ja andmestikku senisest põhjalikumalt analüüsima. Sellise analüüsi teostatavuse kasuks räägib siiski see, et nagu artiklis toodud sõnaraamatunäidetest ilmneb, on seda ka seni osaliselt tehtud; samuti ei pea selline analüüs olema põhjalikum tavapärasest semantilisest ja grammatilisest analüüsist ning konstruktsioonide kirjeldus ei pea olema ammendav ega formaalne.

Kolmandat tüüpi nähtust, produktiivses konstruktsioonis omandatud erandlikku käitumist ja konstruktsioonispetsiifilist tähendust, ei saa aga kirjeldada ka konstruktsiooniplokis. See on ootuspärane, kui keeleline teadmine ei jagune leksikoniks ja grammatikaks, vaid moodustab ühe erineva üldisusastmega sümboolsete üksuste võrgustiku. Seetõttu tuleb sõnaraamatut ja seal sõnaliigimärgenditega indekseeritavat traditsioonilist grammatikat paratamatult täiendada n-ö "konstruktikoniga", kus on võimalik kirjeldada ka produktiivsete konstruktsioonide vormi, tähendust ja kombinatoorseid omadusi.

Eelpool kirjeldatud nähtuste osakaal keeles ja seega nende kirjeldamisega seotud probleemi ulatus tuleb küll alles empiiriliselt kindlaks teha, kuid artiklis püüdsin näidata, et ka juba olemasolevate andmete põhjal võib öelda, et tegemist ei ole üksiknähtustega. Selliste nähtuste avastamise ja märkamise tingimuseks on lähtumine keelemudelist, mis eeldab nende olemasolu. Seetõttu on ka sõnaraamatu koostamisel tähtis, millisest keelemudelist lähtutakse.

\section{Kirjandus}

Croft, William 2001. Radical Construction Grammar: Syntactic Theory in Typological Perspective. Oxford: Oxford University Press.

EKG II = Erelt, Mati; Kasik, Reet; Metslang, Helle; Rajandi, Henno; Ross, Kristiina; Saari, Henn; Tael, Kaja; Vare, Silvi 1993. Eesti keele grammatika. II. Süntaks. Kiri. Tallinn: Eesti Teaduste Akadeemia Keele ja Kirjanduse Instituut.

EKSS = Eesti kirjakeele seletussõnaraamat. I-VII. Tallinn: Eesti Keele Instituut, 1988-2007.

Erelt, Mati 200o. Sihitis. - Tiiu Erelt, Mati Erelt, Maire Raadik, Tiina Leemets, Sirje Mäearu. Keelenõuanne soovitab 2. Tiiu Erelt, Maire Raadik (koost., toim.). Eesti Keele Instituut. Tallinn: Eesti Keele Sihtasutus, 91-97. Vt ka http://www.eki.ee/keeleabi/artiklid2/ sihitis.html (17.12.2007).

Fillmore, Charles J. 2006. The articulation of lexicon and constructicon. - Plenaarettekanne 4. rahvusvahelisel konstruktsioonigrammatika konverentsil Tokyo ülikoolis 1.-3.09.2006.

Fillmore, Charles J.; Kay, Paul; O’Connor, Mary Catherine 1988. Regularity and idiomaticity in grammatical constructions. - Language 64, 501-538.

Goldberg, Adele E. 1995. Constructions: a Construction Grammar Approach to Argument Structure. Chicago: University of Chicago Press. 
Heine, Bernd; Kuteva, Tania 2002. World Lexicon of Grammaticalization. Cambridge: Cambridge University Press.

Kasik, Reet 1968. Omastavalise täiendi subjektilisusest ja objektilisusest mine-konstruktsioonis. - Keel ja struktuur 2. Tartu: Tartu Riiklik Ülikool, 125-139.

Kay, Paul; Fillmore, Charles J. 1999. Grammatical constructions and linguistic generalizations: The What's $X$ doing Y? construction. - Language 75, 1-33.

Koptjevskaja-Tamm, Maria 2001. "A piece of the cake" and "a cup of tea": Partitive and pseudo-partitive nominal constructions in the Circum-Baltic Languages. - Östen Dahl, Maria Koptjevskaja-Tamm (eds). The circum-Baltic languages: typology and contact. Vol. 2. Grammar and Typology. Studies in Language Companion Series 55. Amsterdam, Philadelphia: Benjamins, 523-568.

Muischnek, Kadri 2004. Verbi ja noomeni püsiühenditest eesti keeles. - Keel ja Kirjandus 8, 574-589.

Muischnek, Kadri 2006. Verbi ja noomeni püsiühendid eesti keeles. Dissertationes philologiae estonicae Universitatis Tartuensis 17. Tartu: Tartu Ülikooli Kirjastus.

Pajusalu, Renate; Tragel, Ilona; Veismann, Ann; Vija, Maigi 2004. Tuumsõnade semantikat ja pragmaatikat. Tartu Ülikooli üldkeeleteaduse õppetooli toimetised 5. Tartu: Tartu Ülikooli Kirjastus.

Rätsep, Huno 1978. Eesti keele lihtlausete tüübid. Emakeele Seltsi toimetised 12. Tallinn: Valgus.

Sahkai, Heete 2005. Teonimi perifrastilises verbivormis. - Keel ja Kirjandus 10, 790-807.

Sahkai, Heete 2006. Konstruktsioonipõhise keelekirjelduse võimalustest adessiivse viisi- ja põhjusmääruse näitel. - Keel ja Kirjandus 10, 816-831.

Sahkai, Heete 2007. Keelemudel ja sõnaraamatumudel. - Ettekanne VI rakenduslingvistika konverentsil "Keel ja leksikon", 26.-27. aprillil 2007 Tallinnas.

Sepper, Maria-Maren 2006. Indirektaal eesti 19. sajandi lõpu ja 20. sajandi aja- ja ilukirjanduskeeles. Magistritöö. Käsikiri Tallinna Ülikoolis. Tallinn: Tallinna Ülikool.

Tiits, Mai 1982. Seisundiadverbidest. - Keel ja Kirjandus 1, 17-21.

Traugott, Elizabeth Closs (käsikiri). Constructions, emergent constructions, and the notion of 'newness'. http://dialoguematters.stanford.edu/twiki-dm/bin/viewfile/Main/Work shopThree?rev=1.2;filename=TraugottEmergCxns.doc (17.12.2007).

Veldi, Enn 2006. Uusi võimalusi ühendtegusõnade kajastamiseks eesti-inglise sõnaraamatutes. - Ettekanne V rakenduslingvistika kevadkonverentsil "Keel töises suhtluses”, 20.-21.aprill 2006, Tallinn.

VVS = Viks, Ülle 1992. Väike vormisõnastik II. Sõnastik ja lisad. Tallinn: Eesti Teaduste Akadeemia Keele ja Kirjanduse Instituut.

Heete Sahkai (Eesti Keele Instituut) on lõpetanud Eesti Humanitaarinstituudi romaani filoloogia erialal. Kaitses magistrikraadi Tartu Ülikoolis 2002. a prantsuse filoloogia alal. Alates 2002. a töötab Eesti Keele Instituudis ja on Tallinna Ülikooli doktorant eesti filoloogia erialal. Osaleb "Suure eestiprantsuse sõnaraamatu" koostamises. On uurinud eesti keele süntaksit.

Heete.Sahkai@eki.ee 


\title{
SOME LEXICOGRAPHIC IMPLICATIONS OF A CONSTRUCTION-BASED MODEL OF LANGUAGE
}

\author{
Heete Sahkai \\ Institute of the Estonian Language
}

Construction-based theories of language are the result of the acknowledgement that idiosyncratic and idiomatic phenomena constitute an important part of linguistic knowledge and are often subject to partial regularities. Such phenomena pose problems for many alternative linguistic theories based on lexical projection and compositional semantics, as well as for certain important assumptions of lexicography. One of these is the assumption that distributional patterns divide words into a relatively small set of parts of speech so that the grammatical behaviour of words can be indexed in a dictionary with part of speech tags. Another assumption is that words are relatively automonous entities and thus that their meaning and behaviour in context is determined by their inherent semantic and combinatorial properties.

The paper explores three types of phenomena that pose problems for current lexicographic practices based on these assumptions. The first of these is the exceptional syntactic behaviour of words or word forms that have become entrenched in an idiosyncratic pattern which cannot be described in terms of parts of speech, the second is construction-specific meaning, and the third is idiosyncratic behaviour and/or construction-specific meaning acquired by words or word forms in a productive construction.

It is proposed that the occurrence of the head word or some of its forms in a construction in which it displays idiosyncratic behaviour and/or constructionspecific meaning should be described in a separate structural unit in the dictionary article, similarly to its occurrence in a phraseological unit. It is argued that omitting information about constructions or conflating it with information about the inherent semantic and grammatical properties of the head word would be misleading, especially in learners' dictionaries. The possibility to describe constructions in a dictionary is however limited, as is illustrated by the third phenomenon examined in the paper: productive constructions that contain no fixed lexical material can only be represented in an eventual "constructicon" complementing the lexicon and the traditional grammar.

Keywords: lexicography, Construction Grammar, syntax, Estonian 